\title{
Removal of Cement Mortar Remains from Recycled Aggregate Using Pre-soaking Approaches
}

\author{
Vivian W. Y. Tam ${ }^{1}$ C. M. Tam ${ }^{2}$ and K N. Le ${ }^{3}$
}

\begin{abstract}
With a rising tide of adoption of recycled aggregate (RA) for construction, investigation on ways to improve the quality of RA has been overwhelming. The adoption of RA brings benefits including savings in the limited landfill spaces and the use of natural resources. However, the poorer quality of RA often limits its utilization to low grade applications such as sub-grade activities, filling materials and low grade concrete. The major reason that affects the quality of RA is the large amount of cement mortar remains on the surface of the aggregate, resulting in higher porosity, water absorption rates and thus a weaker interfacial zone between new cement mortar and aggregates, which weakens the strength and mechanical performance of concrete made from RA. This paper attempts to study three pre-soaking treatment approaches; namely ReMortar $_{H C l}$, ReMortar ${ }_{\text {H2SO4 }}$ and ReMortar ${ }_{\text {H3PO4 }}$ in reducing the mortar attached to RA. The results show that the behaviour of RA has improved with reduction in water absorption, without simultaneous exceeding the limits of chloride and sulphate compositions after the treatment. This work has also compared the compressive strength, flexural strength and modulus of elasticity of concrete made from the approaches, which shows marked improvements in quality when compared with those using traditional approaches.
\end{abstract}

Keywords: pre-soaking treatment, recycled aggregate, recycled aggregate concrete, construction

\footnotetext{
${ }^{1 *}$ Corresponding author, Lecturer, Griffith School of Engineering, Griffith University, PMB 50 Gold Coast Mail Centre, Queensland 9726, Australia. Email: v.tam@griffith.edu.au, Tel: 61-7-5552-9278, Fax: 61-7-5552-8065.

${ }^{2}$ Professor, Department of Building \& Construction, City University of Hong Kong, 83 Tat Chee Avenue, Kowloon, Hong Kong.

${ }^{3}$ Lecturer, Griffith School of Engineering,Griffith University, PMB 50 Gold Coast Mail Centre, Queensland 9726, Australia.
} 


\section{Introduction}

Waste management and sustainable construction have recently been strongly advocated in Hong Kong (Shen and Tam, 2002). The construction industry plays a vital role in meeting the needs of society and enhancing the quality of life (Shen and Tam, 2002); (Tse, 2001). However, the industry should ensure consistency of its activities and products with environmental policies and good environmental practices through reduction of wastes (Environmental Protection Department, 2006). It is clear that this approach needs to be promoted in the near future.

The best way to deal with material wastes is not to create it in the first place (Snook et al., 1995; Gavilan and Bernold, 1994). Table 1 summarizes problems of the current practices and recommended measures for controlling construction pollutions at the management and operational levels. Four management measures are highlighted including: i) policy; ii) training; iii) audit; and iv) feedback. In addition, two operational measures on design and construction stages are also considered.

$<$ Table $1>$

To facilitate waste management, encouraging sorting of construction and demolition (C\&D) waste in Hong Kong, the Environment, Transport and Works Bureau of the Hong Kong Special Administrative Region (HKSAR) has issued a technical circular (Ref: 15/2003) on "Waste Management on Construction Sites” guiding practices on sorting and separating various types of construction wastes. Meanwhile, the Hong Kong Housing Authority (HKHA) has trialimplemented a program of selective demolition; one of the projects was in the demolition of a school at Lower Ngau Tau Kok Phase 1 Estate. At the same time, the Buildings Department of HKSAR issued a practice note entitled "Use of Recycled Aggregates in Concrete” in February 
2003 (Buildings Department, 2005) to encourage the adoption of RA for construction activities. The Civil Engineering Department of HKSAR has commissioned a pilot recycling plant at Tuen Mun Area 38 to supply RA to the public works projects earmarked for such purposes. All these motions have triggered this study: exploring ways to improve the quality of RA for wider applications.

\section{Research Significance}

This paper aims to achieve the following objectives:

i) Investigating the current practices of RA in construction;

ii) Identifying the major problems that weaken the quality of RAC;

iii) Developing the pre-soaking treatment methods, namely ReMortar ${ }_{\mathrm{HCl}}$, ReMortar $_{\mathrm{H} 2 \mathrm{SO} 4}$ and ReMortar $_{\mathrm{H} 3 \mathrm{PO}}$, in reducing the amount of mortar attached to RA;

iv) Experimenting the three pre-soaking treatment methods and assessing the benefits possibly gained; and

v) Analyzing the micro-structural behaviour of concrete made using these three pre-soaking treatment methods.

\section{Recycled Aggregate}

Until recently almost all demolished concrete wastes in Hong Kong were deposited in landfill areas which are in short supply. Hence, reducing waste generation is a pressing issue. Concrete is such an essential, mass-produced material like steel and soil, much effort has been made to recycle and conserve them. However, recycling of concrete and other building materials during the building process of new buildings and at the end of the life cycle is very currently inadequately arranged in Hong Kong. Concrete, in fact, can allow repeated recycling, as is the 
case for steel and aluminum (Tomosawa and Noguchi, 2000). Since concrete is composed mainly of cementitious materials, and the powders generated during the production of recycled aggregate can also be reprocessed as cement resources, thus permitting repeated recycling in a fully closed system. Although recycling of concrete demolition waste can provide opportunities for saving resources, energy, time, and money, the quality of Recycled Aggregate Concrete (RAC) is often weakened after adopting RA as reported from many previous research (see Table 2) (Howard Humphreys and Partners, 1994, Torring, 2000). Some examples of reusable concrete waste are tabulated as in Table 3.

$<$ Table 2>

$<$ Table 3>

Although reusing RA reduces the consumption of limited resources and thereby saves costs, it also has shortcomings such as weaker interfacial behaviour between aggregate and cement paste, higher portions of cement mortar attached and lower quality (Aitcin and Neville, 1993, Alexander, 1996, Bentz and Garboczi, 1991, Buch et al., 2000, Coventry, 1999, Farran, 1956, Jia et al., 1986, Kawano, 2000, Keru and Jianhua, 1988, Kwan et al., 1999, Li et al., 2001, Lo, 2000, Mehta and Aitcin, 1990, Mitsui et al., 1994, Mohamed and Hansen, 1999, Olorunsogo and Padayachee, 2002, Popovics, 1987, Ravindrarajah and Tam, 1988, Tasdemir et al., 1998, Tomosawa and Noguchi, 2000, Wang et al., 1999, Xueqan et al., 1987). The deformation properties of concrete mixed with secondary aggregate are more than those of concrete mixed with natural gravel. There are two potential solutions to this problem (Hendriks and Pietersen, 2000): i) substitute 100\% gravel by using secondary aggregate and increase the structure dimensions by $10 \%$; and ii) substitution $20 \%$ natural aggregate by using mixed recycled aggregate, which does not reduce the quality of the concrete, with strength up to 65MPa. 
Although there are many construction projects using RAC, those are only limited to lower-grade applications (Cheung, 2003, Hassan et al., 2000, Poon et al., 2003, Reusser, 1994). RAC cannot provide desirable requirements as normal concrete such as poor strength, high quality variation and high deformation (Benboudjema et al., 2005, Bretschneider, 2004, Environmental Protection Department, 2006, Environmental Transport and Works Bureau, 2006, Khatib, 2005, Tam, 2005, Tam et al., 2005, Yang and Han, 2006). Concrete with recycled aggregate with high porosity, less density and high absorption, tend to be worse in strength and in resistance to freezing and thawing than those made out of ordinary aggregate. Therefore, the following recommendations are proposed to popularise the adoption of recycled aggregate:

(a) The price of RA should be as competitive as virgin aggregate to encourage the use of RA to replace gravel in concrete;

(b) Recommendations and specifications for RA should be provided in promoting its use. A detailed requirement should be provided; including the percentage of RA adoption, application areas, requirement of aggregate properties and strength design. RA should also be promoted to be the secondary materials in building construction;

(c) Since the variety of supply sources causes variations of quality, stricter quality control of RA is required. An authorized party should be responsible for controlling RA quality before adopting these materials;

(d) Other than setting up recycling plants and quality specification or standard, an information network should be established among them (see Figure 1). The network needs to be built up to share the experience in using RA; and 
(e) To classify different types of RA, the following typical criteria are used such as density, water absorption, portion of fine values and content of organic materials. With further studies and research, a standard classification system can be developed.

$<$ Figure 1>

The limited applications of RA are attributable to their poor qualities. To solve the problems of RAC, some techniques need to be developed for improving the quality of RA, such as to minimize the cement portions adhering to recycled aggregate or separate aggregate from cement paste as much as possible to attain the quality comparable to original aggregate (Tomosawa and Noguchi, 2000).

\section{Pre-Soaking Treatment Methods}

Since aggregates generally occupy seventy to eighty percent of concrete volume, its selection and proportioning should be given careful attention in order to control the quality of the concrete structure. In addition to their use as economical filler, aggregates generally provide concrete with better dimensional stability and wear resistance. In choosing aggregates for particular uses, attention should be given to three general requirements: economy of the mixture, potential strength of the hardened mass and probable durability of the concrete structure.

The major difference between RA and ordinary aggregates is the amount of cement mortar attached on the surface of aggregate. When old concrete is crushed, a certain amount of mortar from the original cement mortar remains attaching to the stone particles in the RA, which forms a weak, porous and cracky layer (Tam, 2005, Tam, et al., 2005). The porosity of cement mortar attached can directly influence the properties of the aggregate (Barra and Vazquez, 1998); for 
examples, lower strength, higher water absorption and lower density. Therefore, removing the cement mortar remains is the best method in improving the quality of RA and making it as competitive as the virgin aggregate.

In this study, three pre-soaking treating methods for RA are proposed and compared. The procedure is first to soak the RA in an acidic environment at around $20^{\circ} \mathrm{C}$ for twenty-four hours and then watering with distill water to remove the acidic solvents afterward. Before concrete mixing, twenty-four hours water soaking of RA is stipulated according to the specifications of the Buildings Department (BD) (Buildings Department, 2005). Three acidic solvents are experimented in this paper, namely hydrochloric acid $(\mathrm{HCl})$, sulfuric acid $\left(\mathrm{H}_{2} \mathrm{SO}_{4}\right)$ and phosphoric acid $\left(\mathrm{H}_{3} \mathrm{PO}_{4}\right)$ with concentration of 0.1 mole [if concentrated acid is used, dilute it with distill water with concentration of about 0.1 mole], which are abbreviated as ReMortar ${ }_{\mathrm{HCl}}$, ReMortar $_{\mathrm{H} 2 \mathrm{SO} 4}$ and ReMortar ${ }_{\mathrm{H} 3 \mathrm{PO} 4}$ respectively. A concentration of about 0.1 mole chosen for the acidic solution can provide a suitable acidic environment for the aggregate to remove the old cement mortar and will not lower the aggregate quality. The solution can also be used to effectively improve the aggregate quality. Figure 2 illustrates the pre-soaking treatment procedures while Table 4 shows the symbols used.

$<$ Figure 2>

$<$ Table 4>

As the recommended percentage of RA substitution is limited to 30\% in Hong Kong, 5\%, 10\%, $15 \%, 20 \%, 25 \%$ and $30 \%$ of RA have been experimented using ReMortar ${ }_{H C l}$, ReMortar $_{H 2 S O 4}$ and

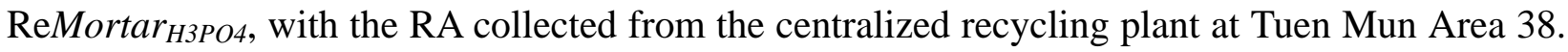
Gradation curves of Aggregate with 20mm and 10mm are shown in Figure 3 and Figure 4, in 
which it shows that the aggregate is within the upper and lower limits of the British standard (BS 882, 1992). The designated mix proportions accord to the specifications of the Buildings Department (BD) (Buildings Department, 2005) with a water to cement ratio of 0.45.

\section{Results}

\subsection{Pre-Soaked Recycled Aggregate}

The water absorption (BS 812: Part 2, 1995), chloride content (BS 812: Part 117, 1988), sulphate content and $\mathrm{pH}$ values of $10 \mathrm{~mm}$ and $20 \mathrm{~mm}$ sized recycled aggregates before and after the three pre-soaking treatment methods are summarized in Table 5.

$<$ Table 5 $>$

\section{$5.2 \quad$ Recycled Aggregate Concrete}

After the pre-soaking treatments, concrete specimens made from the treated RA in the forms of 100mm sized cube, $100 \mathrm{~mm} \times 500 \mathrm{~mm}$ beam, and 100mm diameter cylinder according to British Standard and ASTM Standard (ASTM C293-00, 2001, BS 1881: Part 116, 1983, BS 1881: Part 121, 1983) are prepared to assess their compressive strength, flexural strength and static modulus

of elasticity. The $\mathrm{pH}$ values are also examined. The results are then compared with those made from the normal approach (without any pre-soaking in acidic environment). Each types of experimental work are repeated three times and the average values between them are obtained to reduce the variation between samples and results. The percentages of improvement are recorded and tabulated in Table 6 and Table 7 respectively.

< Table 6>

$<$ Table 7> 


\section{Discussions}

The overall porosity of aggregates depend either upon a consistent degree of particle porosity or represent on the average value for a mixture of variously high and low absorption materials (Hewlett, 1988). Owing to the existence of old cement mortar, the porosity of recycled aggregates is increased. Comparing to natural aggregates, recycled aggregates have higher porosity and thus higher water absorption rates. The water absorption rates for RA are between 3 to 10 percent, compared to less than 1 up to 5 percent for natural aggregates (Building Contractors Society of Japan, 1978); (Hansen and Narud, 1983); (Narud, 1981); (Ravindrarajah and Tam, 1985); (Hasaba et al., 1981). The higher water absorption of the coarse aggregate is resulted from the higher absorption rate of the old cement mortar attached to the aggregate particles (Hansen, 1986); (Kobayashi and Kawano, 1988); (Lamond et al., 2002). This characterizes concrete made with higher water absorption recycled aggregate with reduction in compressive strength and less resistant to freezing and thawing than those with ordinary aggregates (Kobayashi and Kawano, 1988).

Since the cement mortar attached to the RA is the major factor that weakens the mechanical behaviour of concrete, pre-treating RA is necessary to improve their quality. Table 5 shows that the water absorption rates after the pre-treatments have been significantly reduced with improvements between $7.27 \%$ and $12.17 \%$. This shows that the pre-treatments can effectively remove a great portion of old cement mortar from RA, which helps improve the weak link of RA and new cement mortar. Although the chloride and sulphate contents have increased after the pretreatments, they are still within the limits according to the respective standards of $0.05 \%$ and $1 \%$ (Buildings Department, 2005). Regarding the $\mathrm{pH}$ values, the pre-treated RA using ReMortar ${ }_{H C l}$, 
ReMortar $_{\mathrm{H} 2 \mathrm{SO} 4}$ and ReMortar ${ }_{\mathrm{H} 3 \mathrm{PO} 4}$ are still within the alkaline group (above 8.5pH). These show the small adversarial effect to the RA after the acidic pre-treatments.

From the results shown in Table 6, the mechanical properties of recycled aggregate concrete have recorded marked improvements after the pre-treatments. Table 7 shows that 21.84 percent improvement with 20 percent RA substitution is recorded for compressive strength at 7 days curing, 22.90 percent improvement with 25 percent RA substitution recorded for flexural strength at 14 days curing, and 20.48 percent improvement with 30 percent RA substitution for modulus of elasticity when using the ReMortar ${ }_{\mathrm{HCl}}$ approach.

Since the major compositions of cement mortar include calcium oxide $(\mathrm{CaO})$, silicon dioxide $\left(\mathrm{SiO}_{2}\right)$, aluminium oxide $\left(\mathrm{Al}_{2} \mathrm{O}_{3}\right)$ and iron oxide $\left(\mathrm{Fe}_{2} \mathrm{O}_{3}\right)$ (see Table 8), the reactions under the acidic environment are described by Equations (1) to (3), Equations (4) to (6), Equations (7) to (9) for ReMortar ${ }_{\mathrm{HCl}}, \mathrm{ReMortar}_{\mathrm{H} 2 \mathrm{SO} 4}$ and ReMortar ${ }_{\mathrm{H} 3 \mathrm{PO} 4}$ respectively. From that, various reaction products can be generated. However, the unstable reaction products of $\mathrm{Ca}_{3}\left(\mathrm{PO}_{4}\right)_{2} \cdot 3 \mathrm{H}_{2} \mathrm{O}$ and $\mathrm{CaHPO}, 2 \mathrm{Fe}\left(\mathrm{PO}_{4}\right) \cdot 3 \mathrm{H}_{2} \mathrm{O}$ and $\mathrm{FeHPO}_{4}$ generated from $\mathrm{CaO}$ and $\mathrm{Fe}_{2} \mathrm{O}_{3}$ with $\mathrm{H}_{3} \mathrm{PO}_{4}$ [see Equations (7) and (9)], are unable to clean up the most cement mortar attached and limit the benefits gained from the pre-treatment approach with an optimal strength improvement of 14.01 percent (with 25\% RA substitutions at 28 days curing), 18.82 percent (with 5\% RA substitutions at 7 days curing) and 10.82 percent (with 30\% RA substitutions) for compressive strength, flexural strength and the static modulus of elasticity respectively.

\section{$\underline{\text { Reactions under ReMortar }}_{H C l:}$}

$$
\mathrm{CaO}+2 \mathrm{HCl} \rightarrow \mathrm{CaCl}_{2} \cdot \mathrm{H}_{2} \mathrm{O} \quad \text { Equation (1) }
$$




$$
\begin{array}{ll}
\mathrm{Fe}_{2} \mathrm{O}_{3}+6 \mathrm{HCl} \rightarrow 2 \mathrm{FeCl}_{3} \cdot 3 \mathrm{H}_{2} \mathrm{O} & \text { Equation (2) } \\
\mathrm{Al}_{2} \mathrm{O}_{3}+6 \mathrm{HCl} \rightarrow 2 \mathrm{AlCl}_{3} \cdot 3 \mathrm{H}_{2} \mathrm{O} & \text { Equation (3) }
\end{array}
$$

$\underline{\text { Reactions under ReMortar }} \underline{H 2 S O}_{\text {: }}$

$$
\begin{array}{ll}
\mathrm{CaO}+\mathrm{H}_{2} \mathrm{SO}_{4} \rightarrow \mathrm{CaSO}_{4} \cdot \mathrm{H}_{2} \mathrm{O} & \text { Equation (4) } \\
\mathrm{Al}_{2} \mathrm{O}_{3}+3 \mathrm{H}_{2} \mathrm{SO}_{4} \rightarrow \mathrm{Al}_{2}\left(\mathrm{SO}_{4}\right)_{3} \cdot 3 \mathrm{H}_{2} \mathrm{O} & \text { Equation (5) } \\
\mathrm{Fe}_{2} \mathrm{O}_{3}+3 \mathrm{H}_{2} \mathrm{SO}_{4} \rightarrow \mathrm{Fe}_{2}\left(\mathrm{SO}_{4}\right)_{3} \cdot 3 \mathrm{H}_{2} \mathrm{O} & \text { Equation (6) }
\end{array}
$$

$\underline{\text { Reactions under ReMortar }} \underline{\mathrm{H} 3 \mathrm{PO}}_{\mathbf{0}}$

$$
\begin{array}{cc}
2 \mathrm{CaO}+\mathrm{H}_{3} \mathrm{PO}_{4} \rightarrow 2 \mathrm{Ca}^{2+}+\mathrm{H}^{+}+\mathrm{PO}_{4}^{3-}+2 \mathrm{OH}^{-} & \text {Equation (7) } \\
\mathrm{Al}_{2} \mathrm{O}_{3}+2 \mathrm{H}_{3} \mathrm{PO}_{4} \rightarrow 2 \mathrm{Al}^{3+}+3 \mathrm{H}^{+}+2 \mathrm{PO}_{4}^{3-}+3 \mathrm{OH}^{-} & \text {Equation (8) } \\
\mathrm{Fe}_{2} \mathrm{O}_{3}+2 \mathrm{H}_{3} \mathrm{PO}_{4} \rightarrow 2 \mathrm{Fe}^{3+}+3 \mathrm{H}^{+}+2 \mathrm{PO}_{4}^{3-}+3 \mathrm{OH}^{-} & \text {Equation (9) } \\
<\text { Table 8> } &
\end{array}
$$

In ordinary Portland cement concrete, the interfacial zone between cement paste and aggregate exhibits characteristics significantly different from those of the bulk paste (Aitcin and Neville, 1993); (Bentz et al., 1992); (Mehta and Aitcin, 1990); (Mohamed and Hansen, 1999). The quality of interfacial zone depends on surface characteristics of the aggregate particles, the degree of bleeding, chemical bonding and the specimen preparation technique. As RA has been pre-treated, the interfacial zone behaviour of the aggregate with new cement mortar can be enhanced (Alexander, 1996); (Jia, et al., 1986); (Keru and Jianhua, 1988); (Li, et al., 2001); (Popovics, 1987); (Xueqan, et al., 1987) (see Figure 5:, Figure 6 and Figure 7 for the interfacial zone conditions of ReMortar ${ }_{H C l}$, ReMortar ${ }_{\mathrm{H} 2 \mathrm{SO} 4}$ and ReMortar ${ }_{\mathrm{H} 3 \mathrm{PO} 4}$ respectively) when compared with that of the normal approach (see Figure 8 for the interfacial zone condition). As the pasteaggregate bond strength increases, the concrete strength also increases (Mindess et al., 2003). Thus, the weak link of RA leading to its restrictive low grade applications can be removed. 
$<$ Figure 5 $>$

$<$ Figure 6 $>$

$<$ Figure $7>$

$<$ Figure $8>$

The pre-soaking treatment approach should be considered as cost effective as it can directly remove weak links of recycled aggregate and the old cement mortar attached with at a relatively low cost. The improvement after adopting this method has also been shown by many different types of experimental work. Although it needs investment to implement these pre-soaking approaches, the overall quality for RA is greatly improved and be as competitive as the normal aggregate. In comparing the economic point of view, implementing the pre-soaking approaches costs not more than $\mathrm{HK} \$ 500$ for treating about 10 tons of recycled aggregate with quality as similar as the normal aggregate. Otherwise, these recycled aggregate can only be dumped to landfills, which is not beneficial to the environment. It should also be noted that concrete waste may also damage the surrounding environment.

\section{Conclusions}

Using recycled aggregates from demolished concrete wastes has been strongly considered as an effective method for saving the limited landfill spaces and natural resources in Hong Kong. The rare applications of recycled aggregates (RA) for high-grade construction activities are resulted by its poorer and variable quality due to high porosity and water absorption rates. The major reason of this is the cement mortar remains on the surface of RA leading to a porous, highly absorptive and cracky layer during crushing of concrete waste. This paper has studied three presoaking treatment methods: ReMortar ${ }_{\mathrm{HCl}}, \mathrm{ReMortar}_{\mathrm{H} 2 \mathrm{SO} 4}$ and $\mathrm{ReMortar}{ }_{\mathrm{H} 3 \mathrm{PO} 4}$ aiming at reducing 
the old cement mortar attached onto the RA. Experimental results show that the values of water absorption of the pre-treated RA have been significantly reduced with improved mechanical properties for the recycled aggregate concrete. Meanwhile, the alkalinity of recycled aggregate concrete, chloride and sulphate contents of RA have not been adversely affected. Therefore, pretreating the RA is concluded to be an effective method to improve the quality of RA for higher grade utilization that opens up wider applications of RA for construction activities.

\section{Acknowledgments}

The work described in this paper was fully supported by a grant from the Housing Authority Research Fund of the Hong Kong Special Administrative Region, China (Project Ref. No. 9460004).

\section{References}

Acker, A. V. Recycling of concrete at a precast concrete plant. Sustainable construction: use of recycled concrete aggregate: proceedings of the International Symposium, London, UK, London: Thomas Telford, 321-332, 1998.

Ahmed, A. and Struble, L. Effects of microstructure of fracture behaviour of hardened cement paste. Microstructure of cement-based systems/Bonding and interfaces in cementitious materials: symposia, Boston, Massachusetts, U.S.A., 99-108, 1995.

Aitcin, P. C. and Neville, A. M. High performance concrete demystified. Concrete International 1993;15(1): 21-26. 
Alexander, M. G. The effects of ageing on the interfacial zone in concrete. Interfacial transition zone in concrete: state-of-the-art report 1996: 150-174.

ASTM C293-00. Standard test method for flexural strength of concrete (using simple beam with center-point loading). American Society for Testing and Materials, United States, 2001.

Benboudjema, F., Meftah, F. and Torrenti, J. M. Interaction between drying shrinkage, creep and cracking phenomena in concrete. Engineering Structure 2005;27(2): 239-250.

Bentz, D. P. and Garboczi, E. J. Simulation studies of the effects of mineral admixtures on the cement paste-aggregate interfacial zone. ACI Materials Journal 1991;September-October: 518529.

Bentz, D. P., Stutzman, P. E. and Garboczi, E. J. Experimental and simulation studies of the interfacial zone in concrete. Cement and Concrete Research 1992;22(5): 891-902.

Bretschneider, A. The influence of recycled aggregate on the compressive strength and the elastic modulus of concrete. http://www.b-i-m.de/public/tudmassiv/decon98ruehl.htm, 2004.

BS 812: Part 2. Methods for determination of density. British Standards Institution, London, United Kingdom, 1995.

BS 812: Part 117. Methods for determination of water-soluble chloride salts. British Standards Institution, London, United Kingdom, 1988. 
BS 882. Specification for aggregates from natural sources for concrete. British Standards Institution, London, United Kingdom, 1992.

BS 1881: Part 116. Method for determination of compressive strength of concrete cubes. British Standards Institution, London, United Kingdom, 1983.

BS 1881: Part 121. Method for determination of static modulus of elasticity in compression. British Standard Institution, United Kingdom, 1983.

Buch, N., Frabizzio, M. A. and Hiller, J. E. Impact of coarse aggregates on transverse crack performance in jointed concrete pavements. ACI Materials Journal 2000;May-June: 325-332.

Building Research Establishment. Materials control to avoid waste. Building Research Establishment Digest 1982;259.

Buildings Department. http://www.info.gov.hk/bd/english/index.html, 2005.

Chan, A. P. C. and Ma, T. Y. F. Materials wastage on commerical projects - contractor's view. Proceedings of the Sixth East Asia-Pacific Conference on Structure Engineering and Construction, Taipei, Taiwan, 1059-1064, 1998.

Chan, K. Y. and Li, X. D. A study of the implementation of ISO 14001 environmental management systems in Hong Kong. Journal of Environmental Planning and Management 
2001;44(5): 589-601.

Chen, Z., Li, H. and Wong, T. C. Environmental management of urban construction projects in China. Journal of Construction Engineering and Management 2000;126(4): 320-324.

Chen, Z., Li, H. and Wong, T. C. An application of bar-code system for reducing construction wastes. Automation in Construction 2002;11(5): 521-533.

Cheung, H. K. Use of recycled asphalt pavement - a praactical approach to asphalt recycling. Materials Science and Technology in Engineering Conference - Now, New and Next, 2003.

Coffee, M. Cost-effective systems for solid waste management. Waterlines 1999;17(3): 23-24.

Construction Industry Review Committee. Construct for excellence: report of the construction industry review committee. Hong Kong government, 2001.

Coventry, S. The reclaimed and recycled construction materials handbook. London: Construction Industry Research and Information Association, 1999.

Environmental Protection Department. http://www.info.gov.hk/epd, 2006.

Environmental Transport and Works Bureau. Waste management on construction sites. http://www.wb.gov.hk, 2006. 
Farran, J. Contribution of microstructure of minerals and their bonding with Portland cement paste. Rev, Material, Construction, Travel Publics 1956: 490-491.

Frondistou-Yannas, S. Waste concrete as aggregate for new concrete. ACI Journal 1977;5: 373376.

Gavilan, R. M. and Bernold, L. E. Source evaluation of solid waste in building construction. Journal of Construction Engineering and Management 1994;120(3): 536-555.

Grubl, P., Ruhl, M. and Buhrer, M. Evaluation of modulus of elasticity of concrete with recycled aggregate. http://www.b-i-m.de/public/tudmassiv/damcon99grueblruehl.htm, 2004.

Hansen, T. C. The second RILEM state of the art report on recycled aggregates and recycled aggregate concrete. Materials and Structures 1986;1(111): 201-246.

Hansen, T. C. and Narud, H. Strength of recycled concrete made from crushed concrete coarse aggregate. Concrete International: Design and Construction 1983;5(1): 79-83.

Hasaba, S., Kawamura, M. and Toriik, K. Drying shrinkage and durability of concrete made of recycled concrete aggregates. Translation of the Japan Concrete Institute 1981;3: 55-60.

Hassan, K. E., Brooks, J. J. and Erdman, M. The use of reclaimed asphalt pavement aggregates in concrete. Waste Materials in Construction: WASCON 2000: Proceedings of the International Conference on the Science and Engineering of Recycling for Environmental Protection, 
Harrogate, England, 121-128, 2000.

Hendriks, C. F. and Pietersen, H. S. Sustainable raw materials: construction and demolition waste. Cachan Cedex, France, RILEM Publication, 2000.

Hewlett, P. C. Lea's chemistry of cement and concrete. London: Arnold, 1988.

Howard Humphreys and Partners. Managing demolition and construction wastes: report of the study on the recycling of demolition and construction wastes in the UK. London: HMSO, 1994.

Jia, W., Baoyuan, L., Songshan, X. and Zhongwei, W. Improvement of paste-aggregate interface by adding silica fume. Proceedings of the 8th International Congress on the Chemistry of Cement, 460-465, 1986.

Kawano, $\mathrm{H}$. The state of reuse of demolished concrete in Japan. Integrated design and environmental issues in concrete technology: proceedings of the International Workshop 'Rational Design of Concrete Structures under Severe Conditions', Hakodate, Japan, London: E \& FN Spon, 243-249, 1995.

Keru, W. and Jianhua, Z. The influence of the matrix-aggregate bond on the strength and brittleness of concrete. Bonding in Cementitious Composites, Materials Research Society 1988;114: 29-34.

Khatib, J. M. Properties of concrete incorporating fine recycled aggregate. Cement and Concrete 
Research 2005;35(4): 763-769.

Kwan, A. K. H., Wang, Z. M. and Chan, H. C. Mesoscopic study of concrete II: nonlinear finite element analysis. Computers and Structures 1999;70(5): 545-556.

Lamond, J. F., Campbell, R. L., Campbell, J. A., Giraldi, A., Halczak, W., Hale, H. C., Jenkins, N. J. T., Miller, R. and Seabrook, P. T. Removal and reuse of hardened concrete: reported by ACI committee 555. ACI Materials Journal 2002;99(3): 300-325.

Laufer, A. and Jenkins, D. Financial incentives to raise productivity. Journal of the Construction Decision, ASCE 1982;107: 745-756.

Li, G., Xie, H. and Xiong, G. Transition zone studies of new-to-old concrete with different binders. Cement and Concrete Composites 2001;23(4-5): 381-387.

Lingard, H., Graham, P. and Smithers, G. Employee perceptions of the solid waste management system operating in a large Australian contracting organization: implications for company policy implementation. Journal of Construction Management and Economics 2000;18(4): 383-393.

Masood, A., Ahmad, T., Arif, M. and Mahdi, F. Waste management strategies for concrete. http://ink.springer.de/link/service/journals/10022/contents/01/00034/papers, 2001.

McDonald, B. RECON waste minimisation and environmental program. Proceedings of CIB Commission Meetings and Presentations, Melbourne, Australia, RMIT, 14-16, 1996. 
McDonald, B. Implementing a waste managemetn plan during the construction phase of a projecT: a case study. Journal of Construction Management and Economics 1998;16(1): 71-78.

McGrath, C. Waste minimization in practice. Resources, Conservation and Recycling 2001;32: 227-238.

Mehta, P. K. and Aitcin, P. C. Microstructural basis of selection of materials and mix proportions for high strength concrete. High Strength Concrete, Second International Symposium, ACI SP121 1990: 265-279.

Merchant, K. A. Modern management control systems: text and cases. Prentice-Hall, New Jersey, 1997.

Mills, T. M., Showalter, E. and Jarman, D. A cost-effective waste management plan. Cost Engineering 1999;41(3): 35-43.

Mindess, S., Young, F. and Darwin, D. Concrete. 2003, 1-664..

Mitsui, K., Li, Z., Lange, D. A. and Shah, S. P. Relationship between microstructure and mechanical properties of the paste-aggregate interface. ACI Materials Journal 1994;91(1): 30-39. Mohamed, A. R. and Hansen, W. Micromechanical modeling of crack-aggregate interaction in concrete materials. Cement and Concrete Composites 1999;21(5-6): 349-359. 
Nelson, B. 1001 ways to reward employees. Workman, New York, 1994.

Olorunsogo, F. T. and Padayachee, N. Performance of recycled aggregate concrete monitoring by durability indexes. Cement and Concrete Research 2002;32(2): 179-185.

Poon, C. S. Management and recycling of demolition waste in Hong Kong. Waste Management and Research 1997;15(6): 561-572.

Poon, C. S. Management and Recycling of Demolition Waste in Hong Kong. Proceedings, 2nd International Conference on Solid Waste Management, Taipei, Taiwan, 433-442, 2000.

Poon, C. S., Azhar, S. and Kou, S. C. Recycled aggregates for concrete applications. Materials Science and Technology in Engineering Conference - Now, New and Next, 2003.

Poon, C. S., Yu, T. W. and Ng, L. H. A guide for managing and minimizing building and demolition waste. The Hong Kong Polytechnic University, 2001.

Poon, C. S., Yu, T. W. and Ng, L. H. On-site sorting of construction and demolition waste in Hong Kong. Resources, Conservation and Recycling 2001;32: 157-172.

Popovics, S. Attempts to improve the bond between cement paste and aggregate. Materials and Structures 1987;20(115): 32-38.

Ravindrarajah, R. S. and Tam, T. C. Properties of concrete made with crushed concrete as coarse 
aggregate. Magazine of Concrete Research 1985;37(130).

Reusser, R. R. Recycling portland cement concrete pavement at the contractor's option. Aviation crossroads: challenges in a changing world: proceedings of the 23rd air transport conference, Arlington, Virginia, 86-91, 1994.

Rogoff, M. J. and Williams, J. F. Approaches to implementing solid waste recycling facilities. 1994.

Roos, D. I. F. Verification of the dimensioning values for concrete with recycled concrete aggregate. http://www.b-i-m.de/public/TUM/dundeeroos.htm, 2003.

Shen, L. Y. and Tam, W. Y. V. Implementing of environmental management in the Hong Kong construction industry. International Journal of Project Management 2002;20(7): 535-543.

Skoyles, E. R. and Skoyles, J. R. Waste prevention on site. London: Mitchell, 1987.

Snook, K., Turner, A. and Ridout, R. Recycling waste from the construction site. England: Chartered Institute of Building, 1995.

Tam, C. M., Deng, Z. M. and Zeng, S. X. Evaluation of construction methods and performance for high rise public housing construction in Hong Kong. Building and Environment 2002;37: 983-991. 
Tam, W. Y. V., Gao, X. F. and Tam, C. M. Micro-structural analysis of recycled aggregate concrete produced from two-stage mixing approach. Cement and Concrete Research 2005;35(6): 1195-1203.

Tam, W. Y. V., Tam, C. M. and Shen, L. Y. Comparing material wastage levels beween conventional in-situ and prefabrication construction in Hong Kong. Journal of Harbin Institute of Technology 2004;11(5): 548-551.

Tam, W. Y. V., Tam, C. M., Zeng, S. X. and Chan, K. K. Environmental performance measurement indicators in construction. Building and Environment 2005;41(2): 164-173.

Tasdemir, M. A., Tasdemir, C., Akyuz, S., Jefferson, A. D., Lydon, F. D. and Barr, B. I. G. Evaluation of strains at peak stresses in concrete: a three-phase composite model approach. Cement and Concrete Composites 1998;20(4): 301-318.

Teo, M. M. M. and Loosemore, M. A theory of waste bahaviour in the construction industry. Journal of Construction Management and Economics 2001;19(7): 741-751.

Teranishi, K., Kikuchi, M., Dosho, Y. and Narikawa, M. Application of recycled aggregate concrete for structural concrete: part 3 production of recycled aggregate by real-scale plant and quality of recycled aggregate concrete. Sustainable construction: use of recycled concrete aggregate: proceedings of the International Symposium, London, UK, London: Thomas Telford, 143-156, 1998. 
Topcu, I. B. Physical and mechanical properties of concrete produced with waste concrete. Cement and Concrete Research 1997;27(12): 1817-1823.

Tse, Y. C. R. The implementation of EMS in construction firms: case study in Hong Kong. Journal of Environmental Assessment Policy and Management 2001;3(2): 177-194.

Wang, Z. M., Kwan, A. K. H. and Chan, H. C. Mesoscopic study of concrete I: generation of random aggregate structure and finite element mesh. Computers and Structures 1999;70(5): 533544.

Warren, R. H. Motivation and productivity in the construction industry. Van Nostrand Reinhold, New York, 1989.

Xueqan, W., Dongxu, L., Qinghan, B., Liqun, G. and Minshu, T. Preliminary study of a composite process in concrete manufacture. Cement and Concrete Research 1987;17(5): 709-714.

Yang, Y. F. and Han, L. H. Experimental behaviour of recycled aggregate concrete filled steel tubular columns. Journal of Construction Steel Research 2006;Article in Press.

Yangi, K., Hisaka, M. and Kasai, Y. Physical properties of recycled concrete using recycled coarse aggregate made of concrete with finishing materials. Demolition and Reuse of Concrete and Masonry: Guidelines for Demolition and Reuse of Concrete and Masonry: Proceedings of the Third International RILEM Symposium on Demolition and Reuse of Concrete Masonry, London: E\&FN Spon, 379-390, 1993. 
Zeng, S. X., Tam, C. M., Deng, Z. M. and Tam, W. Y. V. ISO 14000 and the construction industry: case study in China. ASCE Journal of Managemetn and Engineering 2002;19(3): 107-115. 
Table 1: : Problems and Recommended Measures for Controlling Construction Waste by Previous Researchers (Building Research Establishment, 1982, Chan and Ma, 1998, Chan and Li, 2001, Chen et al., 2000, Chen et al., 2002, Coffee, 1999, Construction Industry Review Committee, 2001, Environmental Protection Department, 2006, Gavilan and Bernold, 1994, Lam, 1997, Laufer and Jenkins, 1982, Lingard et al., 2000, Masood et al., 2001, McDonald, 1996, McDonald, 1998, McGrath, 2001, Merchant, 1997, Mills et al., 1999, Nelson, 1994, Poon, 1997, Poon, 2000, Poon et al., 2001, Poon et al., 2001, Rogoff and Williams, 1994, Shen and Tam, 2002, Skoyles and Skoyles, 1987, Snook et al., 1995, Tam et al., 2002, Tam et al., 2004, Tam et al., 2005, Teo and Loosemore, 2001, Warren, 1989, Zeng et al., 2002)

\begin{tabular}{|c|c|c|c|c|c|c|}
\hline & \multicolumn{4}{|c|}{ Management Level } & \multicolumn{2}{|r|}{ Operational Level } \\
\hline & Policy & Training & Audit & Feedback & Design & Construction \\
\hline Aim & $\begin{array}{l}\text { Enhance } \\
\text { environmental } \\
\text { awareness and } \\
\text { company culture }\end{array}$ & \multicolumn{2}{|c|}{$\begin{array}{l}\text { Provide benchmarking measures in } \\
\text { understanding the weaknesses }\end{array}$} & $\begin{array}{l}\text { Achieve } \\
\text { continuous } \\
\text { improvement }\end{array}$ & $\begin{array}{l}\text { Have an early planning for } \\
\text { the environmental issues }\end{array}$ & $\begin{array}{l}\text { Ensure all construction wastage had been } \\
\text { minimized by all means }\end{array}$ \\
\hline Problems & $\begin{array}{l}\text { Waste management } \\
\text { as a low priority in } \\
\text { a project }\end{array}$ & $\begin{array}{l}\text { Insufficient } \\
\text { training provided } \\
\text { and lack of } \\
\text { knowledge on } \\
\text { waste minimization } \\
\text { technology } \\
\end{array}$ & $\begin{array}{lr}\text { Normally no } \\
\text { benchmarking tool } \\
\text { provided in an } \\
\text { organization }\end{array}$ & $\begin{array}{l}\text { No } \\
\text { encouragement } \\
\text { to provide } \\
\text { feedback }\end{array}$ & $\begin{array}{l}\text { Lack of consideration of } \\
\text { environmental issues in the } \\
\text { design stage }\end{array}$ & Waste generation is increasing \\
\hline Measures & \begin{tabular}{|l} 
- Set up \\
environmental \\
policy \\
- $\begin{array}{l}\text { Demonstrate } \\
\text { greater }\end{array}$ \\
commitment to \\
waste management \\
- Implement waste \\
management plan \\
- Consider reduction \\
of construction \\
waste and \\
awareness of \\
environmental \\
protection as basic \\
requirements in \\
building \\
management
\end{tabular} & $\begin{array}{l}\text { Provide training } \\
\text { programme to all } \\
\text { levels of } \\
\text { employees }\end{array}$ & $\begin{array}{l}\text { - Provide } \\
\text { benchmarking } \\
\text { measures for } \\
\text { understanding the } \\
\text { problems of the } \\
\text { current measure } \\
\text { and provide some } \\
\text { improvements } \\
\text { - Incentive reward } \\
\text { scheme }\end{array}$ & $\begin{array}{ll}\text { - Provide } \\
\text { feedback loop } \\
\text { from the public } \\
\text { and in-house } \\
\text { employees } \\
\text { - Improve } \\
\text { building } \\
\text { construction } \\
\text { technology by } \\
\text { research or } \\
\text { adoption }\end{array}$ & 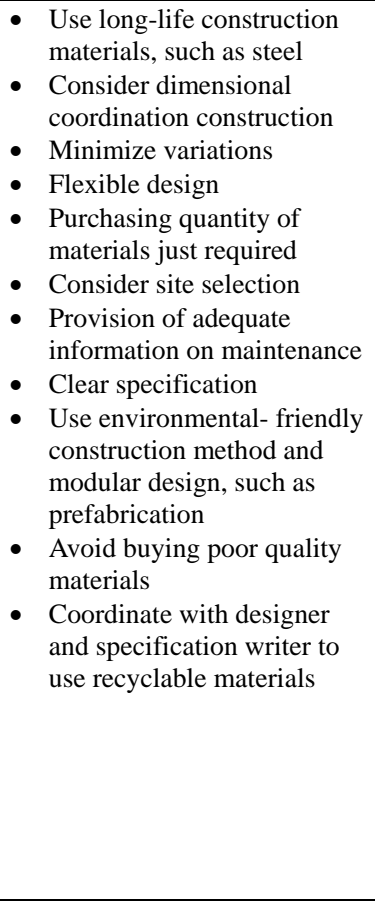 & 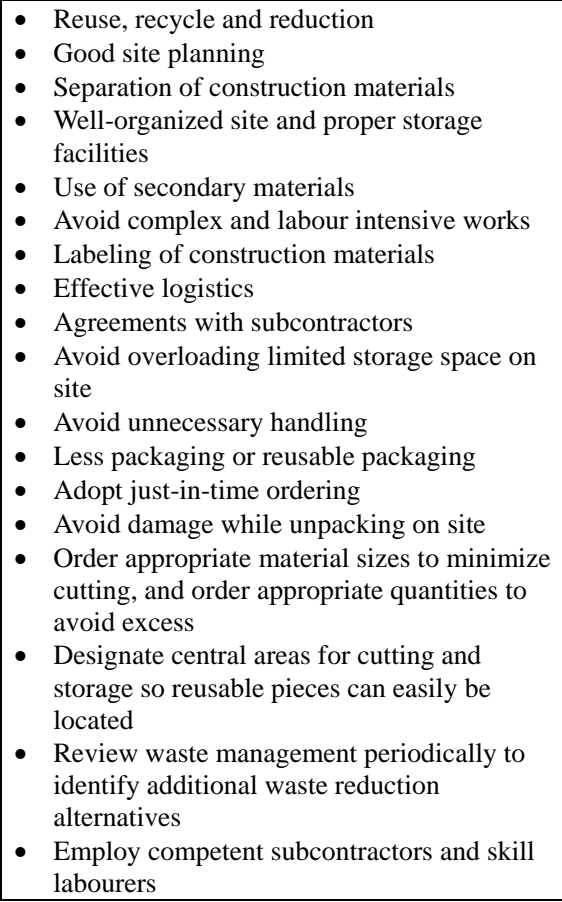 \\
\hline
\end{tabular}


Table 2a: Summary on the Previous Researches on RAC

\begin{tabular}{|c|c|c|c|c|}
\hline Source(s) & $\begin{array}{l}\text { Replacement } \\
\text { ratio }\end{array}$ & $\begin{array}{l}\text { Compressive } \\
\text { strength* }\end{array}$ & Flexural strength* & $\begin{array}{l}\text { Modulus of } \\
\text { elasticity* }\end{array}$ \\
\hline (Acker, 1998) & $\begin{array}{l}100 \% \\
\text { replacement of } \\
\text { coarse recycled } \\
\text { aggregate } \\
\text { (CRA) }\end{array}$ & 17.2\% lower & 20\% lower & 23\% lower \\
\hline $\begin{array}{l}\text { (Ahmed and } \\
\text { Struble, 1995) }\end{array}$ & $\begin{array}{l}100 \% \\
\text { replacement of } \\
\text { CRA }\end{array}$ & 33\% lower & $\begin{array}{c}16 \% \text { lower (at } 14 \\
\text { days) }\end{array}$ & \\
\hline \multirow[t]{3}{*}{$\begin{array}{l}\text { (Bretschneider, } \\
\text { 2004) }\end{array}$} & $\begin{array}{l}100 \% \\
\text { replacement of } \\
\text { CRA }\end{array}$ & & 8.1\% lower & 11.9\% lower \\
\hline & $\begin{array}{l}75 \% \\
\text { replacement of } \\
\text { CRA }\end{array}$ & & & $4.0 \%$ lower \\
\hline & $\begin{array}{l}50 \% \\
\text { replacement of } \\
\text { CRA }\end{array}$ & & 8.1\% lower & $5.8 \%$ lower \\
\hline $\begin{array}{l}\text { (Frondistou- } \\
\text { Yannas, 1977) }\end{array}$ & $\begin{array}{l}100 \% \\
\text { replacement of } \\
\text { CRA }\end{array}$ & $\begin{array}{l}4 \% \text { to } 14 \% \\
\text { lower }\end{array}$ & & $40 \%$ lower \\
\hline \multirow[t]{4}{*}{$\begin{array}{l}\text { (Grubl et al., } \\
\text { 2004) }\end{array}$} & $\begin{array}{l}100 \% \\
\text { replacement of } \\
\text { CRA }\end{array}$ & & & 28.3\% lower \\
\hline & $\begin{array}{l}75 \% \\
\text { replacement of } \\
\text { CRA }\end{array}$ & & & 21.9\% lower \\
\hline & $\begin{array}{l}50 \% \\
\text { replacement of } \\
\text { CRA }\end{array}$ & & & 23.3\% lower \\
\hline & $\begin{array}{l}25 \% \\
\text { replacement of } \\
\text { CRA }\end{array}$ & & & 13.6\% lower \\
\hline $\begin{array}{l}\text { (Hansen and } \\
\text { Marga, 1988) }\end{array}$ & $\begin{array}{l}100 \% \\
\text { replacement of } \\
\text { CRA }\end{array}$ & $30 \%$ lower & & \\
\hline $\begin{array}{l}\text { (Ikeda et al., } \\
\text { 1988) }\end{array}$ & $\begin{array}{l}100 \% \\
\text { replacement of } \\
\text { CRA }\end{array}$ & $\begin{array}{l}15 \% \text { to } 40 \% \\
\text { lower }\end{array}$ & & $\begin{array}{l}30 \% \text { to } 50 \% \\
\text { lower }\end{array}$ \\
\hline $\begin{array}{l}\text { (Kakizaki et } \\
\text { al., 1988) }\end{array}$ & $\begin{array}{l}100 \% \\
\text { replacement of } \\
\text { CRA and fine } \\
\text { recycled } \\
\text { aggregate } \\
\text { (FRA) }\end{array}$ & $32 \%$ lower & & $40 \%$ lower \\
\hline
\end{tabular}




\begin{tabular}{|c|c|c|c|c|}
\hline \multirow[t]{3}{*}{$\begin{array}{l}\text { (Masood, et al., } \\
\text { 2001) }\end{array}$} & $\begin{array}{l}10 \% \\
\text { replacement of } \\
\text { FRA }\end{array}$ & $20 \%$ lower & $4.2 \%$ lower & $32.4 \%$ lower \\
\hline & $\begin{array}{l}20 \% \\
\text { replacement of } \\
\text { FRA }\end{array}$ & $22.6 \%$ lower & 7.3\% lower & $22.7 \%$ lower \\
\hline & $\begin{array}{l}30 \% \\
\text { replacement of } \\
\text { FRA }\end{array}$ & $25.5 \%$ lower & $10.4 \%$ lower & $20.2 \%$ lower \\
\hline $\begin{array}{l}\text { (Nishibayashi } \\
\text { and Yamura, } \\
\text { 1988) }\end{array}$ & $\begin{array}{l}100 \% \\
\text { replacement of } \\
\text { CRA }\end{array}$ & $\begin{array}{c}15 \% \text { to } 30 \% \\
\text { lower }\end{array}$ & & $15 \%$ lower \\
\hline (Roos, 2003)] & $\begin{array}{l}100 \% \\
\text { replacement of } \\
\text { CRA }\end{array}$ & $34 \%$ lower & & $36.4 \%$ lower \\
\hline $\begin{array}{l}\text { (Teranishi et } \\
\text { al., 1998) }\end{array}$ & $\begin{array}{l}50 \% \\
\text { replacement of } \\
\text { CRA }\end{array}$ & $57.8 \%$ lower & & $30.5 \%$ lower \\
\hline \multirow[t]{4}{*}{ (Topcu, 1997) } & $\begin{array}{l}30 \% \\
\text { replacement of } \\
\text { CRA\# }\end{array}$ & $31.8 \%$ lower & & \\
\hline & $\begin{array}{l}50 \% \\
\text { replacement of } \\
\text { CRA\# }\end{array}$ & $45.5 \%$ lower & & \\
\hline & $\begin{array}{l}70 \% \\
\text { replacement of } \\
\text { CRA\# }\end{array}$ & $54.5 \%$ lower & & \\
\hline & $\begin{array}{l}100 \% \\
\text { replacement of } \\
\text { CRA\# }\end{array}$ & $86.4 \%$ lower & & \\
\hline \multicolumn{5}{|c|}{ Notes: * Tests are conduced in the curing of 28 days; and } \\
\hline
\end{tabular}


Table 2b: Summary on the Previous Researches on RAC

\begin{tabular}{|c|c|c|c|c|}
\hline Source(s) & $\begin{array}{l}\text { Replacement } \\
\text { ratio }\end{array}$ & $\begin{array}{l}\text { Compressive } \\
\text { strength* }\end{array}$ & Flexural strength* & $\begin{array}{l}\text { Modulus of } \\
\text { elasticity* }\end{array}$ \\
\hline \multirow[t]{3}{*}{$\begin{array}{l}\text { (Yangi et al., } \\
\text { 1993) }\end{array}$} & $\begin{array}{l}30 \% \\
\text { replacement of } \\
\text { CRA }\end{array}$ & $\begin{array}{c}0.3 \% \text { to } 11.2 \% \\
\text { lower }\end{array}$ & & $\begin{array}{c}0 \% \text { to } 18.7 \% \\
\text { lower }\end{array}$ \\
\hline & $\begin{array}{l}50 \% \\
\text { replacement of } \\
\text { CRA }\end{array}$ & $\begin{array}{c}1.2 \% \text { go } 16.8 \% \\
\text { lower }\end{array}$ & & $\begin{array}{c}2.8 \% \text { to } 25.1 \% \\
\text { lower }\end{array}$ \\
\hline & $\begin{array}{l}100 \% \\
\text { replacement of } \\
\text { CRA }\end{array}$ & $\begin{array}{c}4.1 \% \text { to } 19.7 \% \\
\text { lower }\end{array}$ & & $\begin{array}{c}1.1 \% \text { to } 25.8 \% \\
\text { lower }\end{array}$ \\
\hline
\end{tabular}


Table 3: Reuse of Demolished Concrete (Kawano, 1995)

\begin{tabular}{|c|c|}
\hline Demolished Member & Man-made Reef, Paving Stone \\
\hline Broken into 20 to $40 \mathrm{~cm}$ & Protection of Levee \\
\hline Crushed (-50mm) & $\begin{array}{c}\text { Sub-base, Backfilling, Foundation } \\
\text { Materials }\end{array}$ \\
\hline Crushed and Worn (-40mm) & $\begin{array}{c}\text { Concrete and Asphalt Concrete } \\
\text { Aggregate Sub-Base Material, } \\
\text { Backfilling Material }\end{array}$ \\
\hline $\begin{array}{c}\text { Powder (by-product through } \\
\text { crushing) }\end{array}$ & $\begin{array}{c}\text { Filler for Asphalt Concrete, Soil } \\
\text { Stabilization Materials }\end{array}$ \\
\hline
\end{tabular}


Table 4: Symbols Used for Representing Various Procedures and Materials

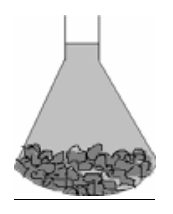

Soaking Aggregate in Acidic Environment

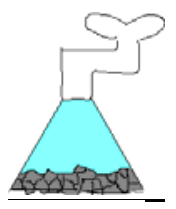

Watering Aggregate with Water

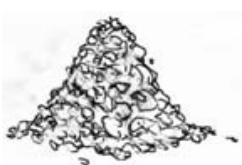

Recycled

Aggregate

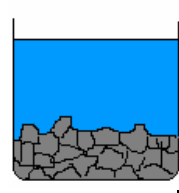

Soaking Aggregate with Water 
Table 5: Properties of Recycled Aggregate before and after Pre-soaking Treatments

\begin{tabular}{|c|c|c|c|c|c|}
\hline \multirow{2}{*}{$\begin{array}{l}\text { Properties of } \\
\text { recycled aggregate }\end{array}$} & \multirow{2}{*}{$\begin{array}{l}\text { Sizes of } \\
\text { aggregate }\end{array}$} & \multirow{2}{*}{$\begin{array}{c}\text { Before } \\
\text { pre-soaking } \\
\text { treatment }\end{array}$} & \multicolumn{3}{|c|}{ After pre-soaking treatment } \\
\hline & & & ReMortar $_{H C l}$ & ReMortar $_{\mathrm{H} 2 \mathrm{SO} 4}$ & ReMortar $_{\text {HзРО4 }}$ \\
\hline \multirow{2}{*}{ Water absorption (\%) } & $20 \mathrm{~mm}$ & 1.65 & 1.45 & 1.48 & 1.53 \\
\hline & $10 \mathrm{~mm}$ & 2.63 & 2.31 & 2.37 & 2.41 \\
\hline \multirow{2}{*}{ Chloride content (\%) } & $20 \mathrm{~mm}$ & 0.0016 & 0.0025 & 0.0001 & 0.0001 \\
\hline & $10 \mathrm{~mm}$ & 0.0012 & 0.0056 & 0.0001 & 0.0001 \\
\hline \multirow{2}{*}{ Sulphate content (\%) } & $20 \mathrm{~mm}$ & 0.0025 & 0.0076 & 0.1090 & 0.0110 \\
\hline & $10 \mathrm{~mm}$ & 0.0025 & 0.0082 & 0.1040 & 0.0109 \\
\hline \multirow{2}{*}{ Value of $\mathrm{pH}$} & $20 \mathrm{~mm}$ & 10.46 & 9.07 & 8.95 & 8.55 \\
\hline & $10 \mathrm{~mm}$ & 11.63 & 9.34 & 9.35 & 9.33 \\
\hline
\end{tabular}


Table 6: Mechanical Properties and pH Values of Recycled Aggregate Concrete for Normal RA and Pre-soaking Treated RA

\begin{tabular}{|c|c|c|c|c|c|c|c|c|c|c|c|c|c|}
\hline \multirow{3}{*}{\multicolumn{2}{|c|}{$\begin{array}{c}\text { Properties of } \\
\text { recycled aggregate } \\
\text { concrete }\end{array}$}} & \multirow{2}{*}{\multicolumn{3}{|c|}{$\begin{array}{l}\text { Normal mixing approach } \\
\text { (days of curing) }\end{array}$}} & \multicolumn{9}{|c|}{ Pre-soaking treatments method (days of curing) } \\
\hline & & & & & \multicolumn{3}{|c|}{ ReMortar $_{\mathrm{HCl}}$} & \multicolumn{3}{|c|}{ ReMortar $_{\mathrm{H} 2 \mathrm{SO} 4}$} & \multicolumn{3}{|c|}{ ReMortar $_{\mathrm{H} 3 Р \mathrm{PO}}$} \\
\hline & & 7 & 14 & 28 & 7 & 14 & 28 & 7 & 14 & 28 & 7 & 14 & 28 \\
\hline \multirow{6}{*}{$\begin{array}{l}\text { Compressive } \\
\text { strength } \\
(\mathrm{MPa})\end{array}$} & $5 \%$ & 45.05 & 53.04 & 57.26 & 46.90 & 53.83 & 59.12 & 52.76 & 56.50 & 61.10 & 47.70 & 54.95 & 59.10 \\
\hline & $10 \%$ & 50.29 & 54.53 & 58.98 & 50.33 & 54.89 & 59.37 & 51.51 & 58.89 & 60.98 & 54.54 & 57.18 & 60.84 \\
\hline & $15 \%$ & 45.14 & 51.72 & 56.26 & 47.31 & 53.73 & 57.59 & 47.82 & 53.62 & 57.93 & 46.97 & 52.32 & 60.67 \\
\hline & $20 \%$ & 42.21 & 51.92 & 53.68 & 51.43 & 54.62 & 59.09 & 43.05 & 56.80 & 59.53 & 43.24 & 52.13 & 53.72 \\
\hline & $25 \%$ & 51.09 & 52.62 & 52.31 & 51.18 & 53.64 & 55.80 & 51.85 & 53.69 & 59.00 & 51.33 & 54.11 & 59.64 \\
\hline & $30 \%$ & 45.49 & 54.58 & 58.07 & 53.00 & 56.28 & 61.07 & 51.49 & 55.87 & 58.84 & 49.40 & 56.16 & 58.80 \\
\hline \multirow{6}{*}{$\begin{array}{c}\text { Flexural } \\
\text { strength } \\
(\mathrm{MPa})\end{array}$} & $5 \%$ & 5.10 & 5.81 & 5.98 & 5.73 & 6.27 & 6.24 & 5.70 & 6.17 & 6.14 & 6.06 & 6.55 & 6.19 \\
\hline & $10 \%$ & 4.74 & 5.02 & 5.49 & 5.50 & 5.44 & 5.60 & 5.30 & 5.41 & 5.77 & 5.24 & 5.88 & 6.51 \\
\hline & $15 \%$ & 4.57 & 5.41 & 6.10 & 5.00 & 5.42 & 6.17 & 5.15 & 5.59 & 6.19 & 5.14 & 5.87 & 6.20 \\
\hline & $20 \%$ & 4.98 & 5.26 & 5.64 & 5.25 & 5.83 & 5.71 & 5.08 & 5.52 & 5.74 & 5.15 & 5.67 & 5.90 \\
\hline & $25 \%$ & 4.73 & 4.76 & 6.08 & 4.97 & 5.85 & 6.35 & 5.13 & 5.41 & 6.13 & 4.83 & 5.59 & 6.18 \\
\hline & $30 \%$ & 4.88 & 4.93 & 6.14 & 5.03 & 5.31 & 6.30 & 5.20 & 5.68 & 6.20 & 5.05 & 5.46 & 6.16 \\
\hline \multirow{6}{*}{$\begin{array}{l}\text { Static } \\
\text { modulus of } \\
\text { elasticity } \\
\left(\mathrm{N}\left(\mathrm{mm}^{2}\right)^{-1^{*}}\right.\end{array}$} & $5 \%$ & \multicolumn{3}{|c|}{31065} & \multicolumn{3}{|c|}{32830} & \multicolumn{3}{|c|}{32573} & \multicolumn{3}{|c|}{33456} \\
\hline & $10 \%$ & \multicolumn{3}{|c|}{29729} & \multicolumn{3}{|c|}{30636} & \multicolumn{3}{|c|}{34298} & \multicolumn{3}{|c|}{31931} \\
\hline & $15 \%$ & \multicolumn{3}{|c|}{30279} & \multicolumn{3}{|c|}{31548} & \multicolumn{3}{|c|}{31013} & \multicolumn{3}{|c|}{30668} \\
\hline & $20 \%$ & \multicolumn{3}{|c|}{29118} & \multicolumn{3}{|c|}{31253} & \multicolumn{3}{|c|}{31437} & \multicolumn{3}{|c|}{31765} \\
\hline & $25 \%$ & \multicolumn{3}{|c|}{29303} & \multicolumn{3}{|c|}{29890} & \multicolumn{3}{|c|}{29320} & \multicolumn{3}{|c|}{31016} \\
\hline & $30 \%$ & & 28194 & & & 33969 & & & 30951 & & & 31245 & \\
\hline & $5 \%$ & & 12.50 & & & 12.61 & & & 12.69 & & & 12.67 & \\
\hline & $10 \%$ & & 12.71 & & & 12.59 & & & 12.71 & & & 12.63 & \\
\hline Scale of $\mathrm{nH}^{*}$ & $15 \%$ & & 12.57 & & & 12.55 & & & 12.69 & & & 12.63 & \\
\hline scale or pн & $20 \%$ & & 12.73 & & & 12.65 & & & 12.81 & & & 12.75 & \\
\hline & $25 \%$ & & 12.20 & & & 12.68 & & & 12.50 & & & 12.64 & \\
\hline & $30 \%$ & & 12.47 & & & 12.81 & & & 12.64 & & & 12.74 & \\
\hline
\end{tabular}


Table 7: Improvement on Mechanical Properties of Recycled Aggregate Concrete after Pre-soaking Treatments

\begin{tabular}{|c|c|c|c|c|c|c|c|c|c|c|}
\hline \multirow{4}{*}{\multicolumn{2}{|c|}{$\begin{array}{c}\text { Properties of } \\
\text { recycled aggregate } \\
\text { concrete }\end{array}$}} & \multicolumn{9}{|c|}{ Pre-soaking treatments method (days of curing) } \\
\hline & & \multicolumn{3}{|c|}{ ReMortar $_{H C l}$} & \multicolumn{3}{|c|}{$\mathrm{ReMortar}_{\mathrm{H} 2 \mathrm{SO} 4}$} & \multicolumn{3}{|c|}{ ReMortar $_{\mathrm{H} 3 P O 4}$} \\
\hline & & 7 & 14 & 28 & 7 & 14 & 28 & 7 & 14 & 28 \\
\hline & & & & $\operatorname{Iml}$ & ovement & en comp & ed with $\mathrm{N}$ & MA & & \\
\hline \multirow{6}{*}{$\begin{array}{l}\text { Compressive } \\
\text { strength } \\
(\mathrm{MPa})\end{array}$} & $5 \%$ & $4.11 \%$ & $1.49 \%$ & $3.25 \%$ & $17.11 \%$ & $6.52 \%$ & $6.71 \%$ & $5.88 \%$ & $3.60 \%$ & $3.21 \%$ \\
\hline & $10 \%$ & $0.08 \%$ & $0.66 \%$ & $0.66 \%$ & $2.43 \%$ & $8.00 \%$ & $3.39 \%$ & $8.45 \%$ & $4.86 \%$ & $3.15 \%$ \\
\hline & $15 \%$ & $4.81 \%$ & $3.89 \%$ & $2.36 \%$ & $5.94 \%$ & $3.67 \%$ & $2.97 \%$ & $4.05 \%$ & $1.16 \%$ & $7.84 \%$ \\
\hline & $20 \%$ & $21.84 \%$ & $5.20 \%$ & $10.08 \%$ & $1.99 \%$ & $9.40 \%$ & $10.90 \%$ & $2.44 \%$ & $0.40 \%$ & $0.07 \%$ \\
\hline & $25 \%$ & $0.18 \%$ & $1.94 \%$ & $6.67 \%$ & $1.49 \%$ & $2.03 \%$ & $12.79 \%$ & $0.47 \%$ & $2.83 \%$ & $14.01 \%$ \\
\hline & $30 \%$ & $16.51 \%$ & $3.11 \%$ & $5.17 \%$ & $13.19 \%$ & $2.36 \%$ & $1.33 \%$ & $8.60 \%$ & $2.89 \%$ & $1.26 \%$ \\
\hline \multirow{6}{*}{$\begin{array}{l}\text { Flexural } \\
\text { strength } \\
(\mathrm{MPa})\end{array}$} & $5 \%$ & $12.35 \%$ & $7.92 \%$ & $4.35 \%$ & $11.76 \%$ & $6.20 \%$ & $2.68 \%$ & $18.82 \%$ & $12.74 \%$ & $3.51 \%$ \\
\hline & $10 \%$ & $16.03 \%$ & $8.37 \%$ & $2.00 \%$ & $11.81 \%$ & $7.77 \%$ & $5.10 \%$ & $10.55 \%$ & $17.13 \%$ & $18.58 \%$ \\
\hline & $15 \%$ & $9.41 \%$ & $0.18 \%$ & $1.15 \%$ & $12.69 \%$ & $3.33 \%$ & $1.48 \%$ & $12.47 \%$ & $8.50 \%$ & $1.64 \%$ \\
\hline & $20 \%$ & $5.42 \%$ & $10.84 \%$ & $1.24 \%$ & $2.01 \%$ & $4.94 \%$ & $1.77 \%$ & $3.41 \%$ & $7.79 \%$ & $4.61 \%$ \\
\hline & $25 \%$ & $5.07 \%$ & $22.90 \%$ & $4.44 \%$ & $8.46 \%$ & $13.66 \%$ & $0.82 \%$ & $2.11 \%$ & $17.44 \%$ & $1.64 \%$ \\
\hline & $30 \%$ & $3.07 \%$ & $7.71 \%$ & $2.61 \%$ & $6.56 \%$ & $15.21 \%$ & $0.98 \%$ & $3.48 \%$ & $10.75 \%$ & $0.33 \%$ \\
\hline \multirow{6}{*}{$\begin{array}{l}\text { Static } \\
\text { modulus of } \\
\text { elasticity } \\
\left(\mathrm{N}\left(\mathrm{mm}^{2}\right)^{-1^{*}}\right.\end{array}$} & $5 \%$ & \multicolumn{3}{|c|}{$5.68 \%$} & \multicolumn{3}{|c|}{$4.85 \%$} & \multicolumn{3}{|c|}{$7.70 \%$} \\
\hline & $10 \%$ & \multicolumn{3}{|c|}{$3.05 \%$} & \multicolumn{3}{|c|}{$15.37 \%$} & \multicolumn{3}{|c|}{$7.41 \%$} \\
\hline & $15 \%$ & \multicolumn{3}{|c|}{$4.19 \%$} & \multicolumn{3}{|c|}{$2.42 \%$} & \multicolumn{3}{|c|}{$1.28 \%$} \\
\hline & $20 \%$ & \multicolumn{3}{|c|}{$7.33 \%$} & \multicolumn{3}{|c|}{$7.96 \%$} & \multicolumn{3}{|c|}{$9.09 \%$} \\
\hline & $25 \%$ & \multicolumn{3}{|c|}{$2.00 \%$} & \multicolumn{3}{|c|}{$0.06 \%$} & \multicolumn{3}{|c|}{$5.85 \%$} \\
\hline & $30 \%$ & \multicolumn{3}{|c|}{$20.48 \%$} & \multicolumn{3}{|c|}{$9.78 \%$} & \multicolumn{3}{|c|}{$10.82 \%$} \\
\hline
\end{tabular}


Table 8: Compositions of Cement (Yangi, et al., 1993)

\begin{tabular}{|c|c|}
\hline Compound & Percentages (\%) \\
\hline Calcium oxide $(\mathrm{CaO})$ & 65.1 \\
\hline Silicon dioxide $\left(\mathrm{SiO}_{2}\right)$ & 21.8 \\
\hline Aluminum oxide $\left(\mathrm{Al}_{2} \mathrm{O}_{3}\right)$ & 4.2 \\
\hline Iron oxide $\left(\mathrm{Fe}_{2} \mathrm{O}_{3}\right)$ & 2.5 \\
\hline Sulfite $\left(\mathrm{SO}_{3}\right)$ & 2.4 \\
\hline Potassium oxide $\left(\mathrm{K}_{2} \mathrm{O}\right)$ & 0.72 \\
\hline Sodium oxide $\left(\mathrm{Na}_{2} \mathrm{O}\right)$ & 0.13 \\
\hline Others & 3.15 \\
\hline
\end{tabular}




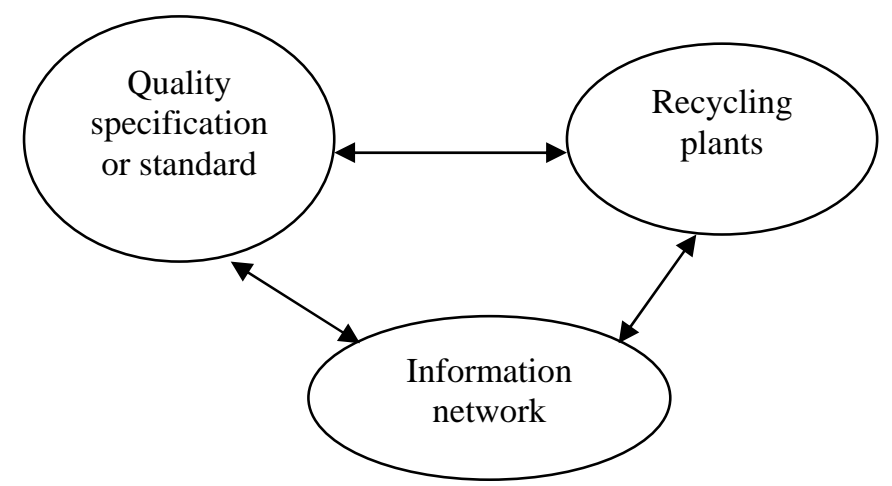

Figure 1: Three Requirements Facilitating Reuse (Kawano, 1995) 


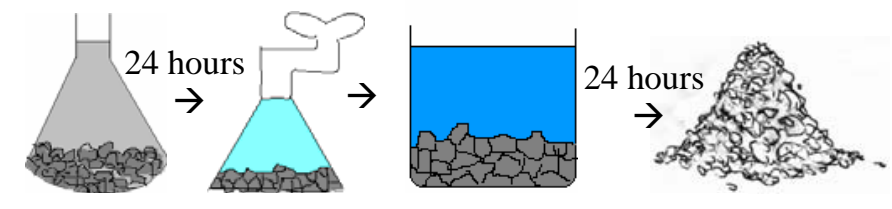

Figure 2: Pre-Soaking Treatment Procedures for Recycled Aggregate 


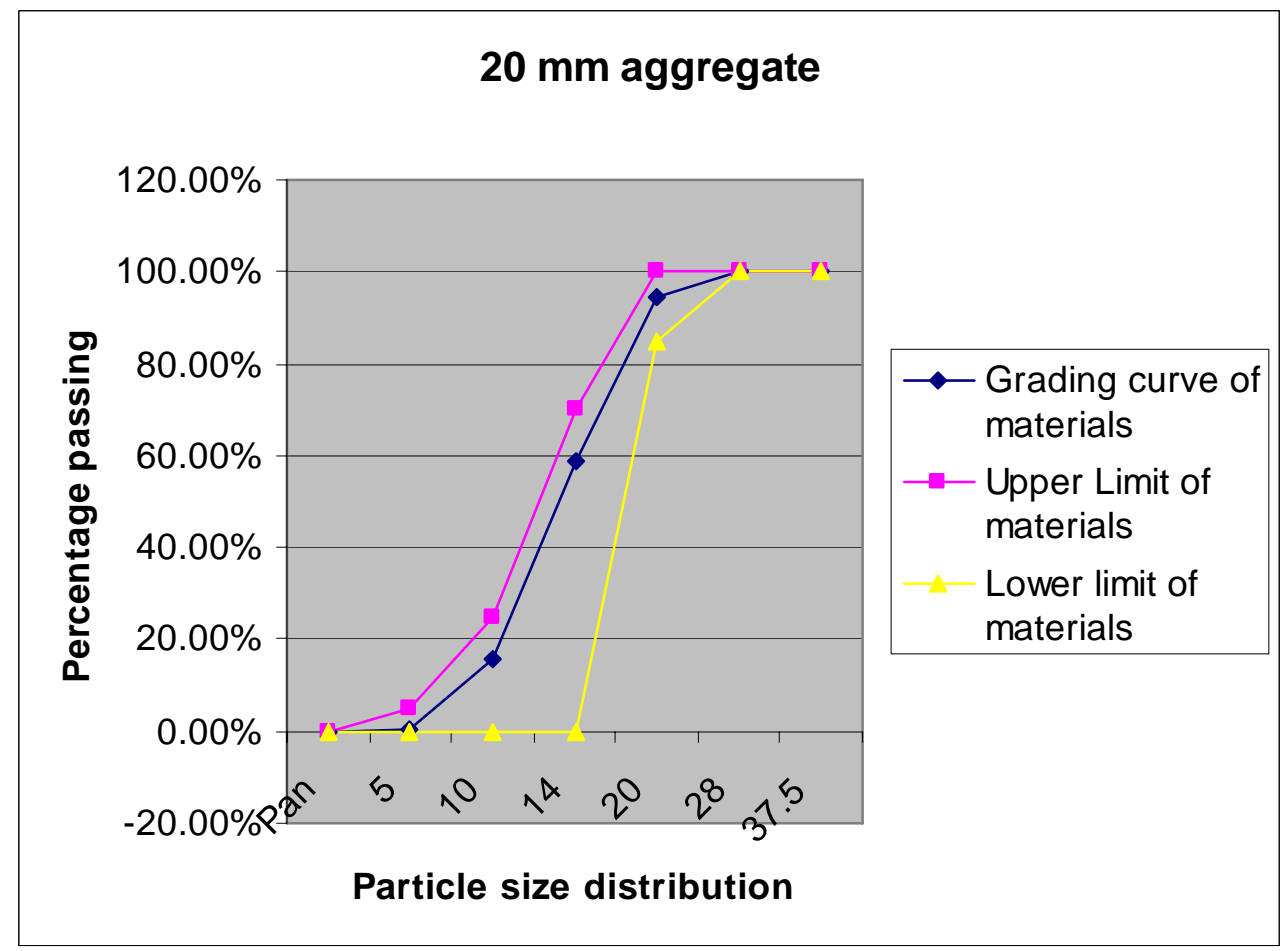

Figure 3: Gradation curve for $20 \mathrm{~mm}$ recycled aggregate 


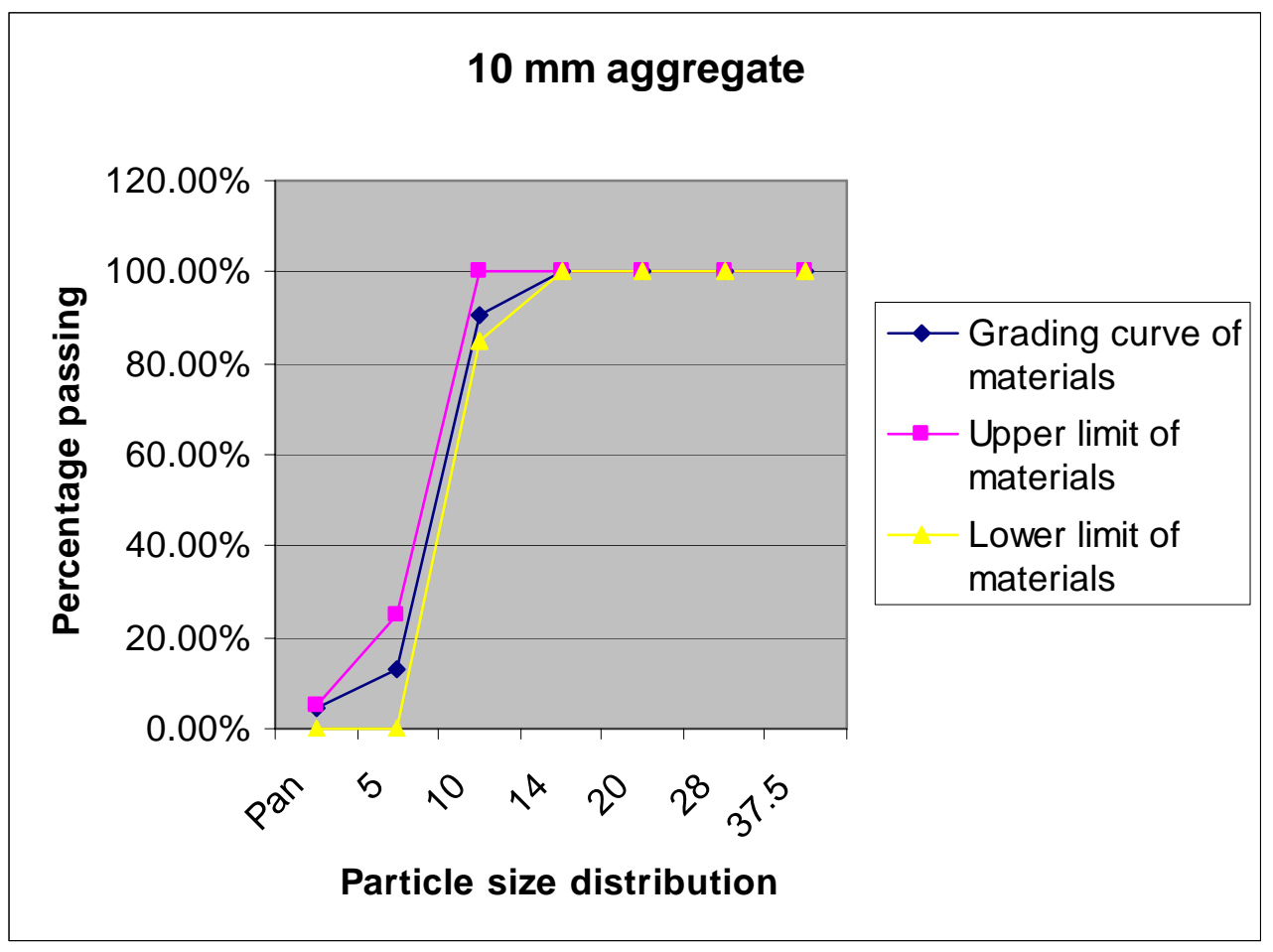

Figure 4: Gradation curve for $10 \mathrm{~mm}$ recycled aggregate 


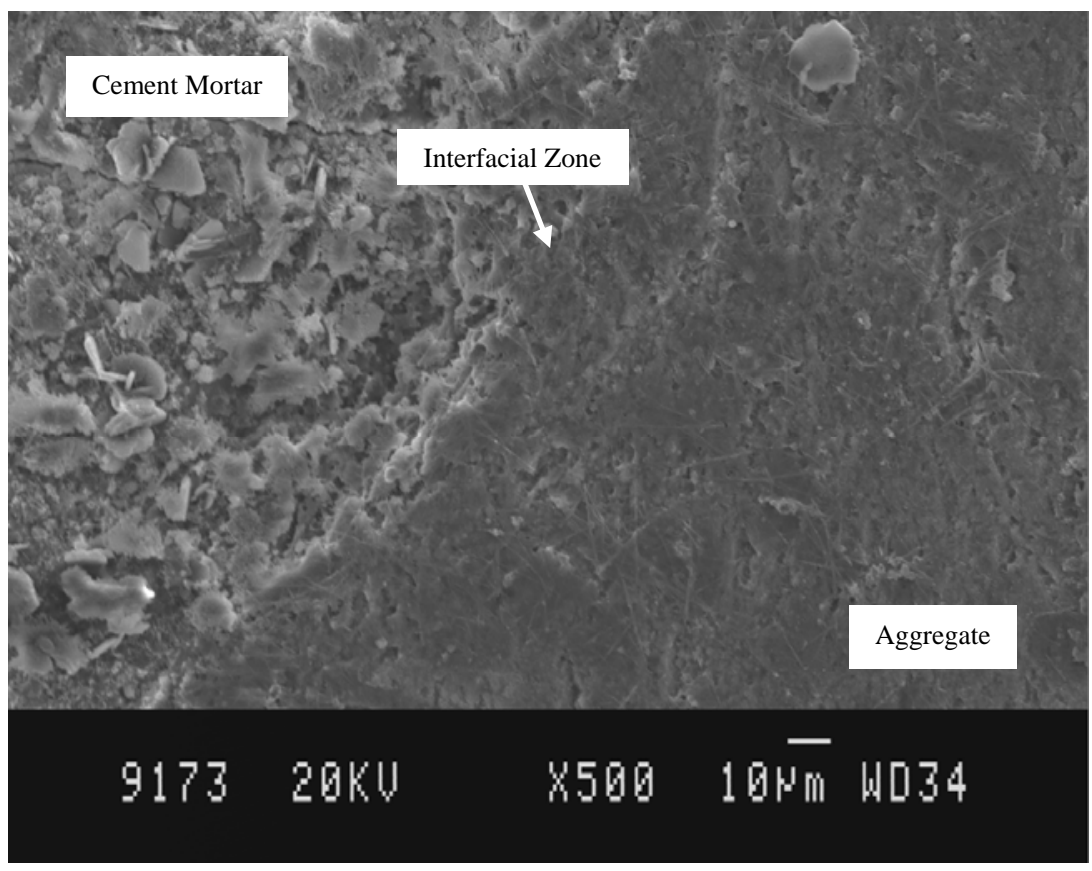

Figure 5: Interfacial Zone for ReMortar $\mathrm{HCl}$ 


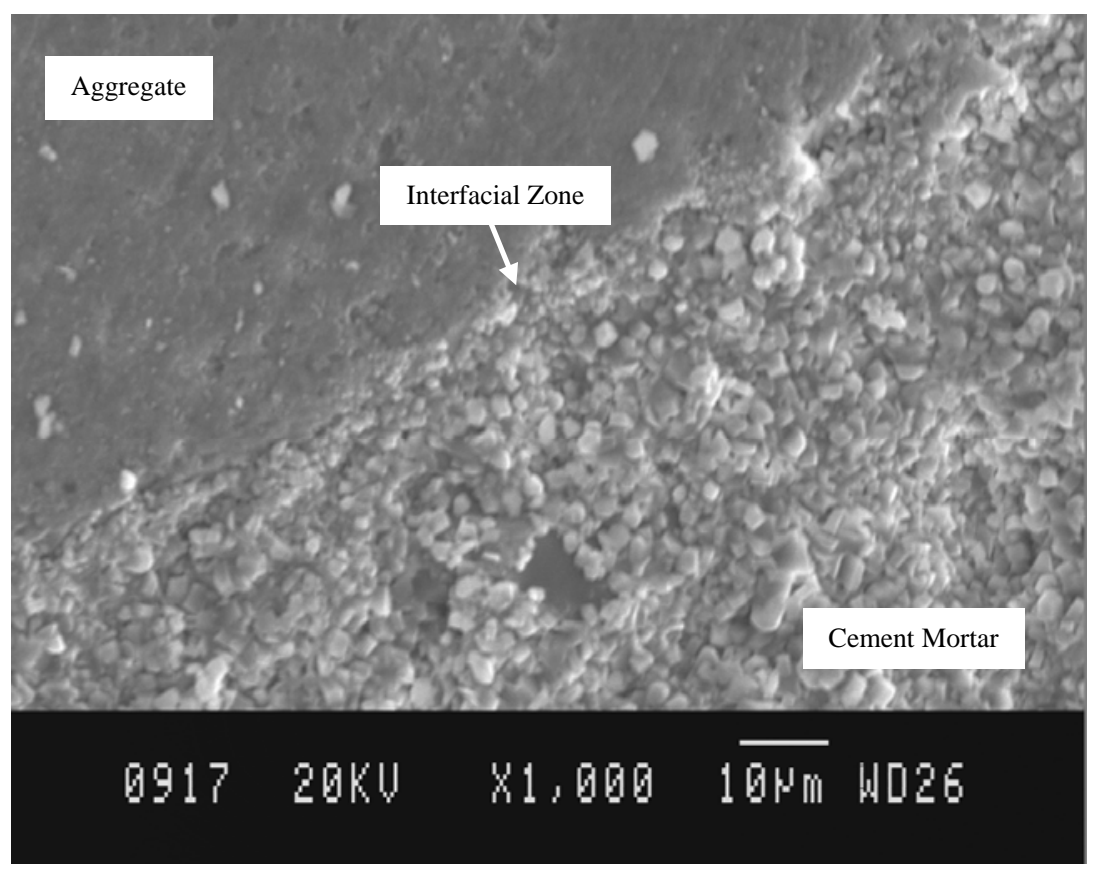

Figure 6: Interfacial Zone for ReMortar ${ }_{\mathrm{H} 2 \mathrm{SO} 4}$ 


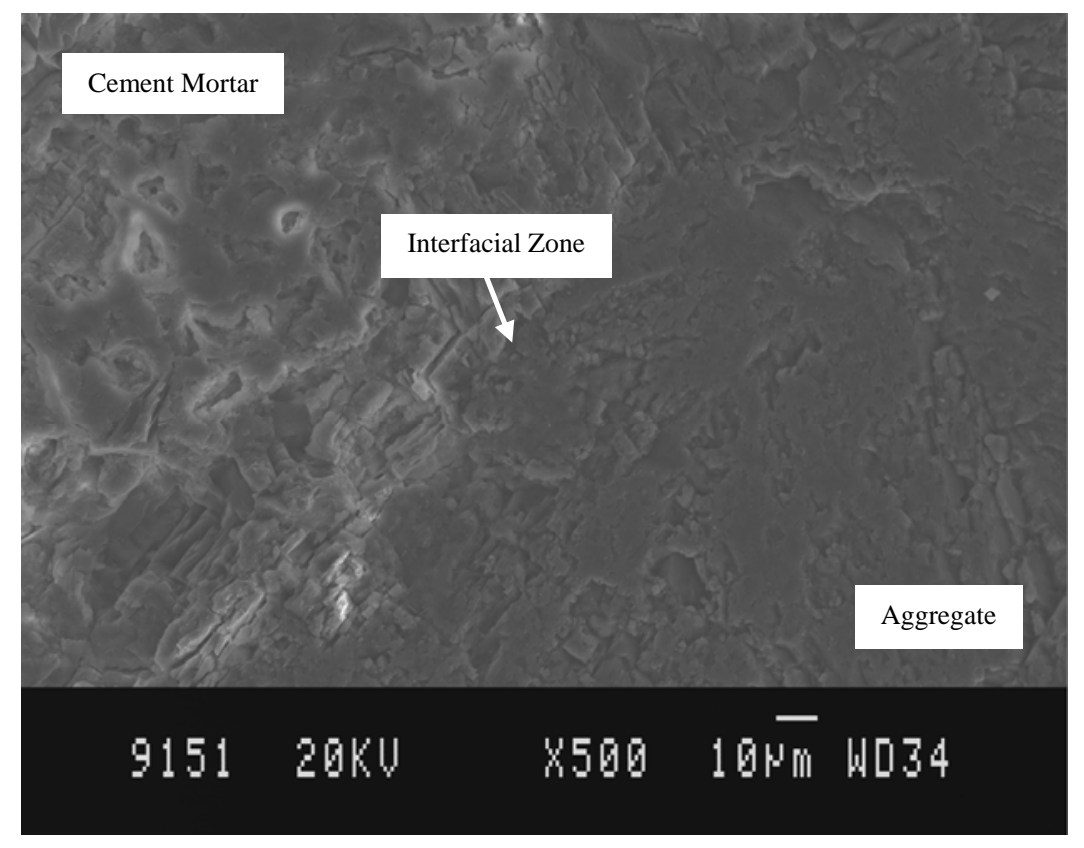

Figure 7: Interfacial Zone for ReMortar ${ }_{\mathrm{H} 3 \mathrm{PO}}$ 


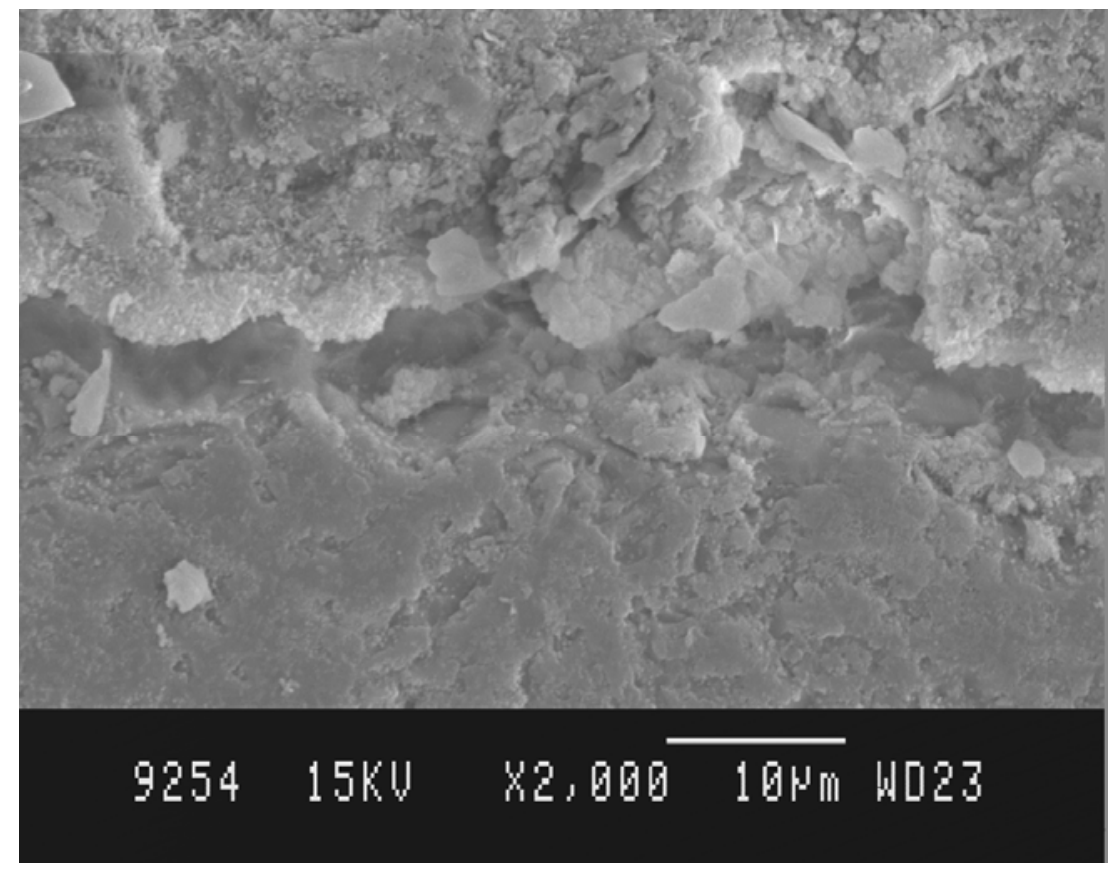

Figure 8: Poorer New Interfacial Zone for Normal Approach (without Pre-soaking Treatments) 